\title{
Analysis Of The Mental Image Of Iranian Consumers Of Foreign Luxury And Widely Used Goods From Non-Marketing Symbols of Seven Countries of Origin
}

\author{
Mostafa Jafari \\ Assistant Professor \\ Department of Management, University of Zanjan \\ Hasti Sadeghi \\ B.S. Student \\ Department of Management, University of Zanjan \\ Shakib Sadeghi \\ B.S. Student \\ Department of Mechanical Engineering, Razi University
}

\begin{abstract}
Which country's expensive, luxury and widely used goods should we buy? What are the non-marketing features of the country of origin as producer or exporter of commodity to Iran, and what is their importance in the mind of Iranian consumer? How are the mental images of various and different Iranian groups of seven known countries in Iran's market, especially with the comparative perspective? This study seeks to explore the answers to these three questions. The study is a descriptive - explanatory and applied research based on the purpose, and quantitative and qualitative one according to variables, a cross-sectional one based on time and a surveying research according to the methodology. The sample size includes 92 citizens and consumers from four provinces of IRAN, including Kermanshah, Zanjan, Tehran and Qazvin. The target population has three parts: Members of the statistical society, five categories of selected luxury widely used goods and seven Country of Origin. The composition of these people consists of all educational degrees, different ethnic groups, distinct age ranges, various high and low-income jobs and people with different political and religious beliefs. Also, about $30 \%$ of the respondents have experienced travelling abroad. Data analysis was conducted by qualitative approach and the questionnaire had face and content validity. The mental images of citizens and consumers from various Iranian ethnic groups, of non-marketing symbols from seven countries of origin are as follows: USA: the symbol of diversity, Germany: symbol of regularity, Japan: symbol of perseverance, Turkey: Symbol of emulation, France: symbol of fashion, UAE: symbol of dependency and China: symbol of plethora. The fact is the future of Iranian market will belong more than before to China.
\end{abstract}

Keywords: mental image, mental image of country of origin, product image, consumer, luxury goods, cultural image, power

\section{INTRODUCTION}

Iranian consumers always pay attention to other countries and have different images of nonmarketing aspects of those countries in mind, which are influenced by several factors such as culture, economic and political power of countries, media, etc. 
We are witnessing a historical process that inevitably transforms the human psyche. Everyone has a model or paradigm in his mind from the world, i.e. a subjective view of an outer reality. This model is made of hundreds of thousands of images. Everyone's mental pattern and model contains images that are very close to reality as well as altered and inaccurate images. As long as the society a person lives in is fixed with slow rate changes, the images based on which he manages his behavior would change slowly as well. A new image, if clearly fits in the format of a subject and coordinates with images already archived there, would not make any problems for us. But if, as often happens, the image is blurred, inconsistent and incongruent, and worst of all, if it is highly inconsistent with our previous conclusions, in this case, our mental model must be revised. We constantly compare the images with each other and join them together. We refer them with new methods and indirectly for matching, and we will again put them elsewhere (Alvin Toffler, 1982). Some believe that image is a kind of subjective knowledge and the result of combining the features of a particular organization. These features include traditions, ideology, company name, credit, price levels, diversity of service and the quality provided in the interactions between people and the company (Nguyen and Leblanc, 1998). Boyle suggest that the concept of image refers to the effect that an entity leaves on people's minds and involves three areas, including the corporate image (peoples 's general attitudes toward the whole organization or company), image of the product (people's attitudes toward a particular class of product), and the image of the brand (people's attitudes toward a particular brand in competition with another commercial brands). (Boyle, 1996). Ecker and Meyer believe that the image refers to a set of meanings by which an entity is recognized and through which, people remember and describe the entity in question (Leminic et al., 2003). Some authors believe that corporate image is the result of the interaction of experiences, feelings, ideas, emotions and knowledge that people have about a company (Gupta and Pyrch, 2008).

\section{RESEARCH BACKGROUND}

Gardner and Levy introduced the concept of product image in their paper in 1955 for the first time. They believed that products have various natures, including physiological and social natures. Since its formal introduction so far, the concept of product image has been used in studies on customer (consumer) behavior. The product image can be a vital concept for marketing managers. In his book, Secrets of Advertising, David Ogilvy claims that he has introduced the concept of brand image in 1953 to the realm of public opinion. He also states that the concept has been first proposed in 1933 by Claude C. Hopkins. Reynolds and Gutman (1984) suggest that people who considering the product image as a character would never accept it, which has been developed to factors beyond the physical aspect of the product. Others, conversely, believe that the image of a brand consists of factors unrelated to the product itself. Jenisch (1978) argues that the concept of product consists of two components, review and measuring characteristics of that brand and imagining the situations, successes, and the like. This theorist rather than using quality- functional issues, has used the psychological concepts of consumer and product in his analysis. He believes that the product image is created and reinforced by broadcast advertisements and their repeating. Friedman (1986) greatly paid attention to psychological concepts, classification of states, priorities and perception - cognitive benefits. Reynolds and Gutman (1984) discussed on the product image components. They offered a certain network, reflecting the memory association with the main components of the product image. Levi (1978) believes that the product image is made by combining the physical reality of the product and character beliefs and feeling built about it.

Keller (2003) stated that in addition to the product manufacturing company, the country or the geographical location from which the product comes from is linked to the brand and its 
associations (Baldayf et al, 2009). The mental image of the country of origin is an important external sign associated with the products with brand-name. Studies have proven the point that consumers rely on the label of "Made in ..." while evaluating a product (Papadopoulos and Heslop, 1993). In developing countries, the consumers do not buy imported goods only for reasons such as low cost or good ratio of quality to price. These consumers have shown that the country of origin is more important to them than the price or packaging (Shantler et al., 2008). The result of a research on the 11 classes of products indicated the effect of the country of origin on willingness to pay extra in the United States (Derodzenko and Jensen, 2009). Thakur and Vekatsanyz (1997) claimed that the symptoms of the mental image of the country directly or indirectly affect (through the brand) the perception of quality. Knowledge and understanding of the perceptions of mental image of the country of origin in target markets and how the consumers communicate with it are crucial at the time of making decision on the place for producing the product. Due to global competition, the use of factors such as where to produce the product is crucial. Due to global competition, the use of factors such as the mental image of the producing country is increasing.

The quality of provided services and the mental image of brands are among the most important factors influencing the consumer's decision0making process that lots of researches have studied them in varying environments. (Rao et al. 2008, Henzaii et al., 2012).

\section{Scientific Foundations Mental Image}

Our minds are made up of a huge network of billions of nerve cells that are all linked together; some directly and some in circuits through other neurons. When we hear a word, a point in our mind network may be activated and makes us to recall the meaning of that word. Hearing a word like "car" or seeing its picture may activate its meaning. Activation is like an electric current that propagates from one point to the outside and activates what is around the word "car" (Sutherland, 2008, 270).

Before you can create an image in the minds of people, you should know what thoughts and association exist in their minds. In research on image, it is important to note the followings:

1) Which attributes in the minds of people matter in referring to the product? 2) Which features distinguish our company from other companies?

The first step is to create things that people recall with a brand or company .These reminders can be vague, semi-structured or even completely wrong. However, they exist .The next step is to determine that the organization wants to emphasize on which virtues of the mental image. When people hear the name of BHP, what do they think? Although this question is somehow a research work, however, strange questions about what people think is important for the studied company should not just be asked. Positive attitudes such as reliability, stability, national interests, humanity, caring, citizen with group responsibility, anti-pollution and sensitive to the environment are all traits that the company can create its image based on them. When an organization reaches a certain image that wants to convey of itself and confirms to introduce itself accordingly, it must then track the public perceptions Subsequently (Ibid., 2005, 257-256).

Mental image is the consumer's imagination of a product, institution, brand, business or a person, which may or may not conform to reality. In business, the image of everything can be more important than its reality. Mental image is the perception of sensory and non-sensory characteristics that describe a brand or a sign. Mental image is a feeling that people gain by 
hearing the name of your company. An image of a business includes facts, events, personal histories and commercial awareness that create a belief in the public mind. Mental image is a set of beliefs, ideas and influences that a person has about an issue. The opinions and actions of people in relation to an issue are strongly influenced by their mental image about that issue (Kotler and Armstrong).

\section{Mental image of Country of origin}

The mental image of the country of origin is an important external sign associated with brandname products, especially when consumers have little knowledge of the foreign products (Hamzavi and Meronca, 2007).

Roth and Romeo (1992) defined the country's mental image as "all the consumers perceptions formed from all products of a given country, based on their previous perceptions of the country's productions and marketing strengths and weaknesses". Roth and Diamantopoulos have stated that the mental image of the country reflects the opinions and feelings of consumers and is the direct result of their knowledge and beliefs, regardless of right or wrong nature of these opinions and knowledge about a specific country. The image of country is the sum of beliefs, ideas and perceptions that a person has about a country (Kerampton, 1979). The image of country is a critical feature in the era of new globalization. Studies shows that geographic areas such as countries, provinces, and cities can be defined as a brand for informing people about places, tourists, costumers and businesses (Keller, 2007).

\section{Product image}

The set of beliefs that people have about a product with specific brand is called the product image. Attitudes and beliefs, in turn, affect the purchaser's behavior. To identify and understand the concept of product image, the customer's attitude and beliefs must be first examined. A person's attitudes and beliefs are gained through the action of learning. People have a special attitude about religion, politics, clothes, music, food and almost anything. Humans have a pattern for their type of perspective, and changing these patterns requires adjustments that barely can be managed to cope with. The consumer's beliefs are the result cognitive learning. These beliefs represent the recognition and inferences that a consumer has about the phenomena, their features and benefits resulting from them. The phenomena here consist of products, people, companies and things that people have comment, opinion and attitudes toward them. Features are characteristics or coordinates of a phenomenon and positive consequences that the phenomena would bring for the consumer. However, it is possible that the consumer's beliefs about the characteristics of a product do not conform to the reality.

\section{Culture and cultural image}

There are different definitions for culture. "Ralph Lynton" defines culture as follows: Culture involves all the imaginations, conditioned emotional responses and normal patterns of behavior that the community members have acquired through education and share them more or less. Culture can be briefly known as a current of ideas that reaches from a person to another through symbolic action, language training, or imitation (Ford 1942). Attitudes, values and beliefs, collectively called culture, have a vital role in human behavior and progress. The culture may refer to the products of any society (Huntington, 1945). According to the definitions of mental image and culture of each region, a new concept can be referred to as the cultural image. Cultural image is a collection of mental images that people have about the cultures of different countries and regions, which as mental image can be close to or far from 
the reality, and is formed under a variety of factors, including the media (which are somehow the major image-makers), foreign travels, the seen and the heard, studies, etc.. Cultural images have a close relationship with mental images and are specific to a particular place with a certain culture and society. These images can be changed and stabilized with the passage of time, changes and events.

\section{Consumer}

According to the definition of Law on Protection of Consumer Rights, a consumer is any real or legal person who buys a product or a service.

\section{Luxury goods}

Luxury goods refers to commodities and services that have exceeded the size and amount of meeting the needs and appear to be a way to show and boast one's money, wealth and capital to the others. In general, the products can be divided into three categories based on the income elasticity:

1. Postal goods: Their income elasticity is less than zero. Postal goods refers to items that when the consumers' income increases, their demand for that product will decrease and vice versa.

2. Essential goods: Their income elasticity is between one and zero. Essential goods are those that the changes percentage in the demand for them is less than the changes percentage in income, and the changes direction is positive (If income increases, the demand increases as well but not as much as the changes size in income).

3. Luxury goods: Their income elasticity is greater than 1 . The changes percentage in demand for luxury goods is more than the changes percentage of income (With increased income, the demand for the goods also increases, but not more than changes in income).

The income elasticity of a product will change according to the consumer's income so that at low income levels, most goods are considered luxury goods, while at average income levels, most goods appear to be essential, and at high income levels, most of the goods are postal (Ahmadi, 2011).

\section{Power}

Power is inherent at all social systems and in all human relationships; it is nothing but an aspect of any relationship or all the relationships among people. As a result, it's inevitable and neutral and inherently is not good or bad. However, among numerous sources of power, three sources symbolically presented in western movies, are violence, wealth and knowledge as the most important ones. Focusing on this triangle and defining power in this format allows us to analyze power by a completely new approach, and perhaps, we can show brighter than ever how power is used to control our behavior from cradle to grave. As human relations are constantly changing, the power relations are in constant process of changing. The relationships between classes, races, genders, professions, countries, and other social groupings have continuously changed due to displacements of populations and ecosystems, technologies, culture and other factors. These changes will lead to conflict and redistribute sources of power (Toffler, 1982). 


\section{Type of research}

\section{RESEARCH METHODOLOGY}

The study is a descriptive - explanatory one based on the purpose, an applied one practical based on the result, a cross-sectional research according to time, a surveying one based on methodology and a qualitative based on data analysis method.

\section{Target population}

The target population of the study included Iranian consumers inside the country. The sample population included 92 people, consisting of 52 men and 40 women aged between 15 and 70 years, who were selected respectively from four provinces of Kermanshah, Zanjan, Qazvin and Tehran. In this study, seven countries included Germany, USA, UAE, Turkey, China, Japan and France.

The combination of biographical features of the research target population members

Table 1:

\begin{tabular}{lcc}
\hline Demographic Features & Frequency & Percentage of Frequency \\
\hline Gender & 52 & 56.52 \\
Male & 40 & 43.48 \\
Female & & \\
Age & 35 & 38 \\
$15-25$ & 27 & 29.34 \\
$25-35$ & 14 & 15.21 \\
$35-45$ & 10 & 10.86 \\
$45-55$ & 5 & 5.43 \\
$55-65$ & 1 & 1.1 \\
above 65 & & \\
Place of Living & 61 & 66 \\
Kermanshah & 15 & 16.5 \\
Zanjan & 9 & 10 \\
Tehran & 7 & 7.5 \\
Qazvin & & \\
Major & 3 & 3.26 \\
Below Diploma & 14 & 15.2 \\
Diploma & 6 & 6.5 \\
Associate & 47 & 51.1 \\
Bachelor & 15 & 16.3 \\
Master & 4 & 4.3 \\
Doctorate & 3 & 3.26 \\
Unknown & &
\end{tabular}

The members of target population were a diverse range of Iranian citizens and consumers with a diverse composition of :

Education composition: Primary to doctoral levels

Ethnic composition: Different ethnic groups and classes (Kurds, Turks, Persians and Lors) Job combination: Various high-income and low-income jobs (engineers, cooks, lawyers, physicians, university professors, workers, drivers, housewives, students, shopkeepers, selfemployed, marketer, civil servants, teachers, psychologists, manager, secretary, nurse, advisor to the governor, poet, etc.)

Belief composition: Diverse political and religious beliefs. 
Income levels: $22.5 \%$ of women and $52 \%$ of men declared their income rate, which occurs in the range of two million Rials to two hundred million Rials.

Foreign travel: $33 \%$ of respondents have had foreign travels $(38.4 \%$ of men and $27.5 \%$ of women).

\section{Sample size and sampling method}

The sample included 92 subjects whom were selected from four cities. The samples were selected by available quota method.

\section{Variables}

Independent variables included: gender, discipline, educational level, age, place of living, foreign travel and income as sample characteristics (consumer) and the priority of purchase, economic power, political power, future market news, political or religious issues and foreign good purchase; the dependent variable was the mental image of Iranian consumers of nonmarketing symbols of the countries of origin.

\section{Quantitative and qualitative nature of variables:}

The study variable can be classified in terms of qualitative and quantitative nature as well. Qualitative classification includes two nominal (e.g., gender) and ordinal (e.g. education) categories, and the quantitative classification is formed of two distance (like the community people) and relative categories like (age).

\section{Data collection tools}

The required data were gathered by two tools: open-ended questionnaire and interviews. The questionnaire contained 16 open-ended questions, which were distributed in written form among 100 numbers, 92 questionnaires were collected within one month from the end of December 2015 till the end of January 2016, and analyzed; the rate of return was 92\%. The questions were:

1. If the goods prices of the following countries are at the same level, then comment your priority to purchase from number 1 to 7? (Germany-France-China-Turkey-Japan -StatsUSA)

2. Please write your mental image briefly about the culture and people of each of the following countries (Germany-France-China-Turkey-Japan-UAE-USA)

3. Write down the most economically powerful countries by order (Germany-FranceChina-Turkey-Japan. -Stats-USA).

4. What are the most powerful countries politically in order? (Germany-France-ChinaTurkey-Japan- UAE- USA).

5. Do political issues and news affect your purchase? (Explain, if needed).

6. Do racial and religious issues influence your foreign products purchase? (Explain, if needed).

7. Which countries will have better status in Iran respectively in terms of market situation? (Germany-France-China-Turkey-Japan -UAE-USA).

8. In your opinion, the most appropriate brands of cars, laptops, mobile phones, shoes, beauty products and cosmetics belong to which one of these following countries (Germany-France-China-Turkey-Japan -UAE-USA) (write them separately.).

9. Why Iranian people are interested in foreign products and brands?

10. What do you suggest to resolve the weaknesses of Iranian products? 


\section{The study questionnaire had content and face validity.}

Since, after determining the exact title for the subject a multi-stage process of preparing the questionnaire was conducted under the supervisor professor review and its problem were fixed, its content validity is approved.

\section{INTERVIEW}

A number of 45 subjects of our sample (20 men and 25 women) have answered orally to the questions. There were 10 people of merchandise and whole sailors and retailors among the interviewers.

The interviews were performed as field study at the workplace or education place of the interviewers in the cities of Kermanshah, Zanjan, Tehran and Qazvin. The time of interviews occurred from the last week of December 2015 to the middle of January 2016. According to the research subject, the following conceptual model is appropriate.

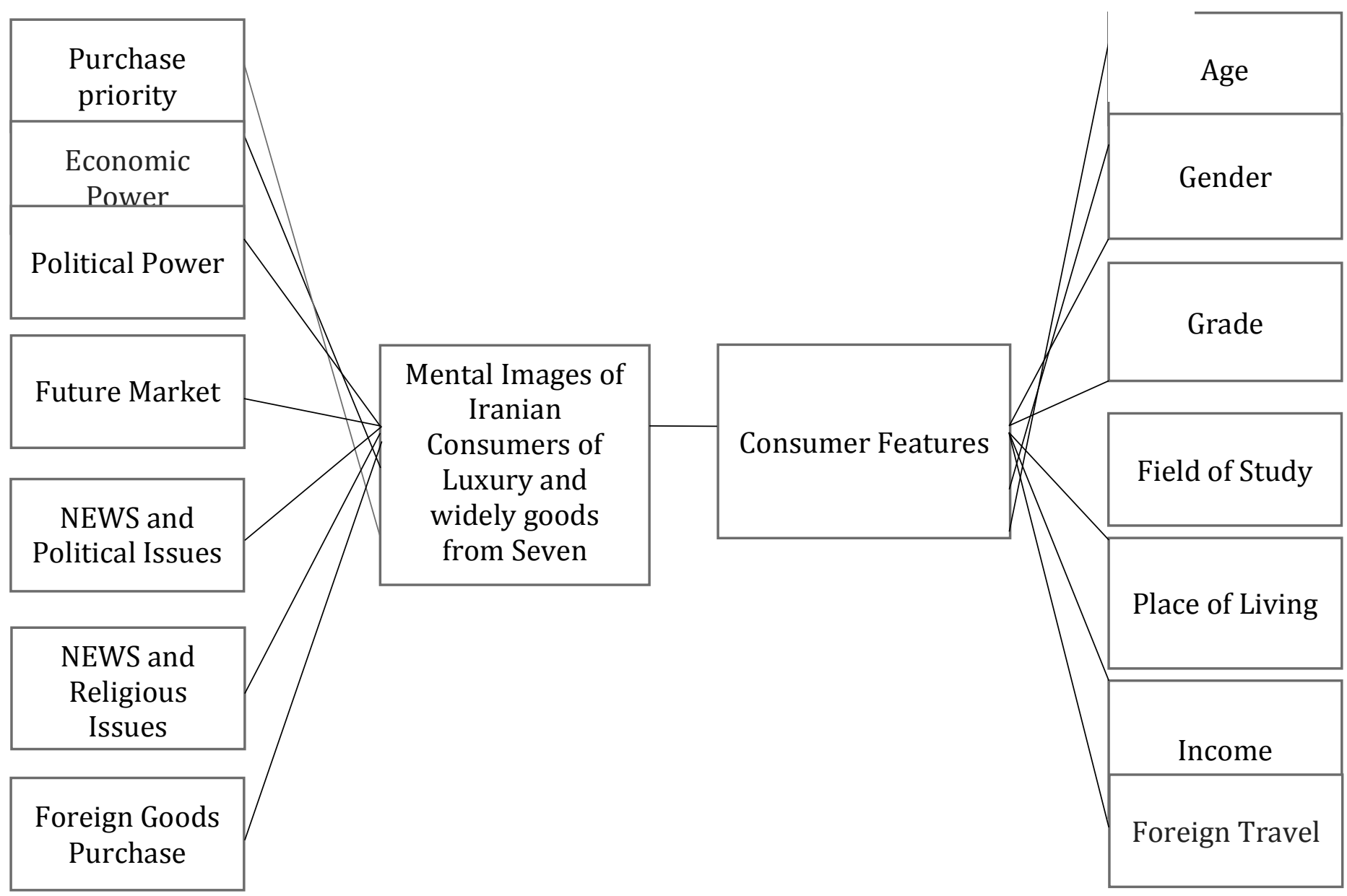

\section{FINDINGS}

The mental image of cultures/Cultural image of the target countries and evaluating nonmarketing symbols

When the people were asked about their mental image of the people and cultures of the following countries, they seemed to be faced with a vague concept. Then, it was explained to 
them that the names of each of these countries (especially in terms of culture and people) would evoke which symbol, word, concept or identity in their minds.

\section{Germany, symbol of regularity (order)!}

The most frequent word that people (40.75\%) refer directly (44.2\% of Men, $37.5 \%$ of Women) is the discipline and lawfulness of the Germans. In addition, they know Germans as cool white people with negative population growth, some soulless, arid like a machine, very accurate and punctual, disciplined and orderly, legal and regulatory, patriot (nationalist) and somehow racist, quiet and high-class, cultured and civilized, active and academic, punctual and sporty, unflinching and serious, strong and diligent. Some have noted the name of Germany is the reminiscent of Mercedes-Benz cars, soccer (Bayern Munich), Aryan race, new religious ideas, Hitler and Nazism, Berlin Wall, technology, advanced and Industry, open economic and political space, driving rules, German sausages, Alarm for Cobra11, clean air and immigration. In general, homogeneous and positive images can be realized from Germany.

\section{USA symbol of diversity!}

USA is the cradle of diversity and freedom and the Americans are known as active but unreasonable, lovely but arrogant, frank and blunt, strong and politician, prosperous and enlivening. It is a free country with nice people, logical and sometimes pasty, the people who are aware of the details of the Fame of the world of cinema and music.

\section{France, the Symbol of Fashion}

French people are well-known for being enthusiastic fans of art, literature, and poetry, as well as being footloose, rackety, prodigal, hypocritical, racist, romantic, and great followers of fashion. These people are also known for pursuing pure social freedom and advocating women's rights.

France is counted as the cultural and artistic capital of the world and the country associated with fragrance, architecture, various museums, the Eiffel Tower, wine, cheese, cooking, theater, history, festivals and tourists. In general, relatively homogeneous images are perceived from France.

\section{Japan, the Symbol of Determination}

Japan is a symbol of pragmatism and persistence in attempting. More than $60 \%$ of surveyed people noted directly the endeavor, punctuality, perseverance, high activity, and the discipline. The slight and hard-working residents of this country activity almost follow the ants' system in activity.

Other surveyed people mentioned distinct, rich and sublime cultural, cultural commitment, integrity, accuracy, intelligence, education and awareness, pioneering the technology in line with tradition, advanced subway system, planning and scheduling, belief and faith, literature, love and emotion, respecting the rights, economic power, high quality of work, responsibility, legality, teamwork and coordination, creativity, robotic invention and remarkable success.

Not referring to even one negative aspect, it became obvious that a positive and homogeneous image of this country is impressed in people's minds. According to the surveyed people's standpoints, Japan is the most moral country in the seven questioned countries. 


\section{China, the Symbol of excess}

Chinese people are considered as being strict, hard-working, disciplined, low-paid, highlypopulated, gentle, calm, tireless, sometimes apathetic, rich and specialty-oriented, active, and profit-driven.

China's vast territory is the reminiscent of empires, civilizations, history, industry, diverse and sometimes shoddy merchandise, low-quality and cheap goods, and numerous people and commodities. Perception of China seems to be somewhat contradictory and heterogeneous.

\section{UAE, the Symbol of Dependence}

UAE is considered as the west's heaven on earth, a dependent country with a relatively poor culture. Its people are almost low-educated, businessmen, consumers, exporters of west products, of low creativity, lazy, and opportunistic. The surveyed people believe that most people from UAE abuse the imported money to this country by immigrants, and are drowning by the money earned from selling oil. Positive perceptions of this country include some luxurious aspects like tourism, modernity, grand shopping centers, and towering skyscrapers. In general, the most negative viewpoints were dedicated to UAE.

\section{Turkey, the Symbol of Imitation}

Some people consider the culture of this Iran's neighbor close to the Persian culture. Others would think that Turkish people are happier and more civilized. Amongst the surveyed people, nearly $40 \%$ mentioned that Turkey is an imitator of European countries; a country with a perverted movie industry, which seeks to take advantage of opportunities.

Most people from west Iran don't have a great perception of Turkey and assume its people coward, rackety, selfish, hollow-minded, and racist.

Turkey's name implies the perception of cloth and clothing, tourism and entertainment, Antalya and Istanbul, and Turkish Kebab to the mind.

The people's impressions of this country are relatively contradictory and different.

It's remarkable that the people who have traveled to Turkey or are Turkic-speaking, possess more positive points of view towards Turkey. However, the recent politics of its government have decreased its general popularity.

\section{Iranian Consumers' Perceptions of Economic Power of Target Countries}

Amongst women, $65 \%$ would consider USA as the top economic power of the world, which is not a wrong impression. As the most economically powerful country, $15 \%$ of them voted to Germany, $10 \%$ to China, $10 \%$ to Japan, and $2.5 \%$ to UAE. Only $25 \%$ of the polled women had a true judgment of China as being the second economically powerful country.

Also, $56 \%$ of surveyed men, knew USA as the country with highest economic power, while $20 \%$ of them voted for Germany, $10 \%$ voted to Japan, and 4\% voted to UAE as the most powerful country in economic affairs. Just $20 \%$ of men correctly recognized China as the second economically powerful country, and $16 \%$ of them did it right for Japan as the third one. 


\section{Iranian Consumers' Perceptions of Political Power of Target Countries}

Almost $90 \%$ of the polled women considered USA as the top country politically, while just $15 \%$ of them dedicated this position to China. $47.5 \%$ of these women counted on France, and 10\% of them on Germany as the country with the highest political power.

However, amongst men, $88 \%$ voted to USA and 26\% voted to China as the first and second most powerful countries in political affairs, respectively.

It's notable that mostly Japan is not voted as a leading power in military or politics, while the statistics show the reverse.

\section{The Effect of News and Political Issues on Shopping}

Among men, 63.4\% considered news and political issues as an effective factor on their shopping, while $34.6 \%$ voted the reverse and $2 \%$ of the votes were abstentions.

Amongst women, 57.5\% considered this factor as an effective one on purchasing imported merchandise, and the remaining $42.5 \%$ allocated no influence to this factor.

Some mentioned that news, dollar local price, exchange rate, legal verdicts and political issues were effective on their purchases. Others have pointed out that they disregarded the news, didn't watch it, or didn't read it, and quality of the goods, the need to purchase, and their personal opinions were the important parameters in shopping.

\section{The Effect of Religion and Race on Shopping}

Among men, 53.8\% have considered racial and religious matters neutral in their shopping, and $44.2 \%$ voted for the reverse, and the remaining $2 \%$ were abstentions.

The percentage of women who knew the racial and religious issues ineffective in shopping was equal to $42.2 \%$, and $57.5 \%$ of them believed these matters as effective factors.

Among the surveyed people, some indicated that racial issues were not effective in their shopping decisions, but they considered religious matters relatively influential. Three people mentioned that they prefer products of none-Islamic countries, and some emphasized purchasing from Islamic countries.

\section{Mind and Shopping Priorities}

A thought-provoking question, with its generality, challenged the respondents. The question was that "Regardless of the cost and the budget, which country attracts your mind?" Some answered with a pause, "Well, it depends on what is being bought.", but the question was beyond it and measured the priority of priorities according to the respondents' minds.

Amongst the male respondents, $42 \%$ voted for USA, 36\% for Germany, $18 \%$ for Japan, $2 \%$ for Turkey, and 2\% for France as their first priority of the country that their purchase would be made in. Also for their last priority, 46\% voted for UAE, 40\% for China, 10\% for Turkey, and $2 \%$ for France. No male one chose Germany, USA, or Japan as their last priorities, or UAE, or China as their first priorities.

A ratio of $42.5 \%$ of the female respondents chose USA as their first priority for the country they'd rather to buy from, while 35\% of them voted for Germany, $10 \%$ for Japan, 5\% for France, and 2.5\% for Iran. As they were asked for their last priority, 55\% voted for UAE, 35\% 
for China, and 7.5\% for USA. None of them chose Germany, Japan, Turkey or France as their last priority, or China, or UAE as their first one.

\section{Internal Perceptions and Future Market Projections}

Regarding the previous impressions of trade relations and cross-country markets, and the changes established and stabilized in people's minds due to time passing and media activities, the future of market was predicted.

As the country with the most promising markets, amongst polled men, 33.5\% voted for China, $17.64 \%$ for Germany and USA, $15.68 \%$ for Japan, $7.8 \%$ for Turkey, and 5.8\% for France. The remaining $1.9 \%$ had no idea about this issue.

However, among female respondents, $40 \%$ anticipated that China would have the best trading markets in future, while $22.5 \%$ voted for USA, $17.5 \%$ for Germany, $12.5 \%$ for Japan, 5\% for Turkey, and $2.5 \%$ for France.

All in all, considering the male and female respondents as a whole, 36.75\% voted for China, $20.07 \%$ for USA, $17.57 \%$ for Germany, $14.09 \%$ for Japan, and $6.4 \%$ for Turkey as the country with the best position in trading markets in the future.

USA, China and to some extent Turkey, have two specific feedbacks, especially USA. The percentage $(19.7 \%)$ of who believe that USA has the most promising foreign markets in Iran, is so close to the percentage $(18.6 \%)$ of whom predicted the lowest participation of USA in foreign markets.

The best average (from 1 to 7 ) and lowest dispersion in the ratings were gained by Germany (3.1) and Japan (3.35), respectively. It means that the most positive images of the future of trading markets are dedicated to Germany and Japan. Among all the surveyed countries, the most negative attitude was towards the UAE; some even recommended the elimination of this country from the surveying.

As a matter of fact, amongst the exporting markets in 2014, China had the first ranking with an income of 7.2 billion dollars, and the third ranking was gained by UAE with an income of 4.9 billion dollars. In the same year, among the countries with greatest importing markets to Iran, China had the first position, UAE gained the second one, and Turkey was in the fourth position, with the budgets of 10.4 billion dollars, 7.8 billion dollars, and 3 billion dollars, respectively. It can be inferred from these statistics that the expectations of respondents about China was close to the reality, and about UAE and Turkey, the anticipations and the reality were quite different.

\section{People's Interests in Foreign Merchandise}

The most common definition of service quality in the literature is based on the overall judgment of the consumer on the superiority of the product or service (Zeithaml, 1988). Quality of service depends on the type of service (Ladhary, 2009).

A ratio of $67 \%$ of male participants and $79 \%$ of females ( $73 \%$ of the total respondents) directly mentioned the high quality of foreign goods as the main reason of their popularity. These qualities included beauty, durability, technology, variation in material, design and color, packaging, valid warranty, proper advertisements and so on. Also satisfying background, 
confidence, good mentality and experience, are other reasons of foreign goods popularity amongst Iranian people. Some believed that domestic production was a total failure and unable to compete with foreign products. Others pointed to foreign luxuries and high quality of foreign goods.

\section{Attitudes of Consumers toward luxurious and highly-consumed goods of target foreign countries}

As Table 2 and Table 3 shows, respondents have dedicated the best car brand to Germany, the best brand of laptop, smartphone, and shoes to USA, and the best cosmetic brand to France. It is remarkable that some of the surveyed people didn't know which brand belonged to which country, and just assigned the brands to the countries based on their false judgments or what they had already heard. They would assign a brand to a wrong country without any research, which could be due to perceptual error (HALEIE), e.g. as they knew USA as a highly powerful country in economic, political, and production fields, they would assign other worldwide valid trademarks to this country. Some of the polled people thought Asus was an USA brand, while it was Taiwanese, or some others recognized Nike brand as a German one, which was in fact an USA one. Amongst the female respondents, there were people with specific interests in Turkey and France, who did think best smartphone and laptop brands were from these two countries. Some of the discussed brands included Timberland, Nike, and Adidas in shoe industry, Golden Rose, Avon, Gosh, and Flormar in cosmetic industry, Apple, HP, Dell, Sony, Asus, and Acer in laptop industry, Nokia, Samsung, and Apple in smartphone industry, and BMW, Mercedes Benz, and Toyota in automobile industry.

The perceptions of the respondents in popularity of the laptop brands were close to the extracted statistics. Among the polled people, there was a shoe seller who mentioned the high quality and superiority of Italian shoes and in the next ranking, the $1^{\text {st }}$ grade Chinese shoes.

In cosmetic brands discussion, it's remarkable that the youngest female participant (15 years old) was the only one who believed, whether consciously or unconsciously, the Japanese brands were the bests among cosmetic brands, which was close to the reality as there are about 7 Japanese brands (Shiseido brand as the best of them) amongst the 50 top cosmetic brands.

Although in some resources, the French brand of L'Oréal has the best ranking, there are more USA popular cosmetic brands in such ranking lists. It's notable that there are some relatively small European countries amongst the top manufacturers of cosmetic products, while Iranian people are undoubtedly unaware of them in cosmetic field.

Although the respondents mentioned France as the owner of top cosmetic brands, all in all it can be perceived that the Iranians' attitudes towards top cosmetic products are in contrary with valid resources. This incorrect impression can be the outcome of different factors. 
Table 2: Mental Images of Iranian Female Consumers of 5 Luxury and widely goods from 7 Origin Countries

\begin{tabular}{|l|l|l|l|l|l|l|l|l|}
\hline $\begin{array}{l}\text { Co } \\
\text { Good }\end{array}$ & Germany & U.S.A & U.A.E & Turkey & China & Japan & France & Other \\
\hline car & 49.4 & 32.5 & & & & 11.2 & 6.8 & \\
\hline Laptop & 7 & 50.5 & & & 5 & 21 & 7 & 9.5 \\
\hline $\begin{array}{l}\text { mobile } \\
\text { phone }\end{array}$ & 2 & 47.5 & & 2 & 13.3 & 24.4 & & 10.8 \\
\hline $\begin{array}{l}\text { shoe } \\
\text { cosmetics }\end{array}$ & 14 & 37.5 & 2 & 29.1 & & 2 & 4.1 & 4.1 \\
\hline
\end{tabular}

Table 3: Mental Images of Iranian Male Consumers of 5 Luxury and widely goods from 7 Origin

\begin{tabular}{|c|c|c|c|c|c|c|c|c|}
\hline \multicolumn{9}{|c|}{ Countries } \\
\hline${ }^{0} 4 n_{4 y}$ & Germany & U.S.A & U.A.E & Turkey & China & Japan & France & other \\
\hline $\begin{array}{l}\text { Good } \\
\text { car }\end{array}$ & 53 & 33 & & & & 7 & 4 & 3 \\
\hline lap top & 8 & 49 & & & 3 & 37 & & 3 \\
\hline $\begin{array}{c}\text { mobile } \\
\text { phone }\end{array}$ & 5 & 55 & & & 6 & 26 & 5 & 3 \\
\hline shoes & 16 & 35 & & 26 & 2 & 9 & 3 & 9 \\
\hline cosmetics & 8.5 & 7.5 & 1 & 16.5 & 2 & 1 & 54.5 & 9 \\
\hline
\end{tabular}

The most favorite image of car belongs to Germany with the rate of $53 \%$ males and $49.4 \%$ females.

The most favorite image of lap top brand belongs to U.S.A, consisting of $49 \%$ males and $50.5 \%$ females.

The best image of mobile phones belongs to the USA, including $55 \%$ males and $47.5 \%$ females.

The best image of shoes belongs to USA, including 35\% males and $37.5 \%$ females. 
The most favorite image of cosmetics belongs to France with $54.5 \%$ males and $45.5 \%$ females' votes.

\section{DISCUSSION AND CONCLUSIONS}

First Result: People's impressions are directly related to political and economic powers of countries. Regardless of the funding, what rules the minds of the people on shopping, determines their priority of choosing and buying items.

Second Result: No pattern and model of reality is entirely a personal product. While some perceptions of humans are based on direct observations, a significant and growing portion of these images are created based upon the messages sent by the media and the people around. So, the accuracy of human patterns in a society partly reflects the general level of knowledge in that community. As much as experiences and scientific research inject more precise and more accurate knowledge into the society, new concepts and new ways of thinking surpass the old ideas and visions, conflict with them, and make them forgotten (Toffler, 1982).

3rd Result: According to the perceptions of Iranian consumers from various ethnic groups on non-marketing icon, each country, amongst the seven origin ones, can be assumed as a symbol; USA the symbol of diversity, Germany the symbol of discipline, Japan the symbol of determination, Turkey the symbol of imitation, France the symbol of fashion, UAE the symbol of dependence, and China the symbol of excess.

$4^{\text {th }}$ Result: $42 \%$ of Iranian people set their first priority of the country to buy its products from USA, $35.5 \%$ chose Germany, and $14.4 \%$ opt for Japan. As their last priority, $37.7 \%$ chose China, and $50 \%$ voted to UAE.

$5^{\text {th }}$ Result: Respondents knew the top automobile brands are produced by Germany, the top laptop, smartphone, and shoes brands are owned by USA, and the best cosmetic brands are produced by France manufacturers.

$6^{\text {th }}$ Result: Generally, the future markets of Iran will be more dependent on China, however China gained the lowest percentage in mental image of the respondents of 5 luxury and widely goods.

$7^{\text {th }}$ Result: The attitudes and impression of people are formed by their observations, previous backgrounds, transferred experiences from past generations, and a noticeable role of culture, religion, race, media, news, political and economic affairs, awareness, and so on. These impressions may be close to or totally different from the reality and would change over time periods.

\section{SUGGESTIONS AND CRITICISMS}

One of the respondents, who was a shoes seller with a remarkable background in his business in west of Iran, mentioned a trading tip that can be named as a social asset gained via reciprocal trust; accepting the retuned goods from the customers along with warranty and guaranty creates a favorable image in costumers' minds.

He pointed out that the inhabitants of western and southern regions of Iran have relatively larger feet than the other parts of Iran. Thus, the produced shoes by manufacturers of central regions of Iran are smaller than usual, and when given the feedback to manufacture on proper 
shoes regarding the regional needs, there would be no proper response from them but "find the fitting customer!".

Another instance would be comparing the sturdy safe USA automobiles with the low-quality locally produced ones that are the main cause of numerous death in Iran.

Improvement of the activities of Chamber of Commerce and import and export companies is considered as an effective factor, because via proving the economic and productive abilities of a country, credibility and confidence will rise in the minds of manufacturers and consumers. In fact, to change and improve the perceptions of consumers, the perceptions of manufacturers need to be changed and improved first.

\section{References}

Toffler, Alvin, Future Shock, translation H. Kamrani, Tehran, publish Translator, First Edition, 1372

Sutherland, Max, advertising and the consumer's mind, the translation of the Sina Qorbanlou, Tehran, Moballeghan Pub, 1383

Kotler, Philip Armstrong, Gary, Principles of Marketing, translated by Ali Parsian, Tehran, publishing Adabestan, 1383

Agylvy, Davy, advertising secrets, translation kourosh Hamidi \& Ali Forouzfar, Tehran, Moballeghan Pub 1382

Toffler, Alvin, power handling, translation Shahindokht Khwarizmi, a new publishing culture Press

Hadi Moradi, great Zarei, Journal of Scientific Research of the new marketing year, the third number, autumn and winter 1390 Page 109-128

Certain Jahangir, Theory and Culture, Publishing Center for Cultural Research, Pages: 28

Huntington, Samuel, cultural significance, translation of Management Development Association Iran, Amir Kabir publication, page 81

Assyrians, Darius, definition and concept of culture, knowledge dissemination, Page: 70

Regulations Article 1 paragraph (c), Law on Protection of Consumer Rights, a consumer definition

Ahmadi, Reza, luxury goods sales strategy, new frontiers Management magazine, Issue 30, p. 20, 1389.

Ladhari, R. (2009). Service quality, emotional satisfaction, and behavioural intentions. Managing Service Quality. 3: $1085-1108$

Zeithaml, V.A. (1988). Consumer perceptions of price, quality, and value: a means-end model and synthesis of evidence. J Mark., 52: 12- 22.

Roth, M. S., \& Romeo, J. B. (1992). Matching product category and country image perceptions: A framework for managing country-of-origin effects, Journal of International Business Studies, Vol. 23, No. 3, pp. 477-497

Hamzaoui, L., \& Merunka, D. (2007). Consumers' product evaluations in emerging markets: Does country of design, country of manufacture, or brand image matter? International Marketing Review, Vol. 24, No. 4, pp. 409426

Nguyen, N., \& Leblank, G. (1998). The Mediating Role of Corporate Image on Customers' Retention Decisions: An Investigation in Financial Services. International Journal of Bank Marketing, 16(2), 52-65.

Boyle, E. (1996). An Experiment in Changing in Corporate Image in Thefinancial Services Industry in UK. The Journal of Services Marketing, 10, 56-69.

Lemminik, J., Schujif, A., \& Stereukens, S. (2003). The Role of Corporate Image and Company Employment Image in Explaining Application Intentions. Journal of Economic Psychology. 24, 1-15.

Gupta, Sh., \& Pirsch, J. (2008). The Influence of a Retailer's Corporate Social Responsibility Program on ReConceptualizing Store Image. Journal of Retailing and Consumer Services, 15, 516- 526. 
Jafari, M., Sadeghi, H., \& Sadeghi, S. (2017). Analysis Of The Mental Image Of Iranian Consumers Of Foreign Luxury And Widely Used Goods From Non-Marketing Symbols Of Seven Countries Of Origin. Advances in Social Sciences Research Journal, 4(7) $122-138$.

Ryu, K., Han, H., Kim, T.H. (2008). The relationships Among Overall Quick Casual Restaurant Image, Perceived Value, Customer Satisfaction, and Behavioral Intentions. International Journal of Hospitality Management, 22, 980469.

Keller, K. L. (2003). Strategic brand management: Building, measuring, and managing brand equity, Upper Saddle River, New Jersey, Pearson Education Inc.

Baldauf, A., Cravens, K., Diamantopoulos, A. ,\& Zeugner-Roth, K.P.(2009). The impact of product-country image and marketing effort on retailer-perceived brand equity: An empirical analysis, Journal of Retailing, Vol. 85, No. 4, pp. 437-452

Papadopoulos, N., \& Heslop, L. A.(1993). Product-Country Images; Impact and role in International Marketing, Journal of International Marketing, Vol. 3, No. 2, pp. 107-109

Schnettler, B., Ruize, D., Sepulveda, O., \& Sepulveda, N.(2008). Importance of the country of origin in food consumption in a developing country, Food Quality and Preference, Vol. 19, pp. 372-282

Takor, M., \& Katsanis, L. (1997). A model of brand and country effects on quality dimensions: Issues and implementations, Journal of International Consumer Marketing, Vol. 9, No. 3, pp. 70-100

Drozdenko, R., \& Jensen, M. (2009). Translating country-of-origin effects into prices, Journal of Product \& Brand Management, Vol. 18, No. 5, pp. 371-378

http://www.irica.gov.ir/Portal/Home/

http://www.beautypackaging.com/heaps/view/2017/1/

http://brandirectory.com/league_tables/table/top-50-cosmetics-brands-2015

http://www.laptopmag.com/articles/laptop-brand-ratings 